\title{
Impact of ICT tools for Combating Cyber Crime in Nigeria Online Banking: A conceptual Review
}

\author{
Fadare Olusolade Aribake
}

\begin{abstract}
ICT information communication technology uprising already has impact virtually in almost every area of human effort. In the mid 1990's, banking sector in the utmost part of the world was meek and dependable, but since the arrival of the technology era, the banking area saw exemplar change in the marvel, ICT also fetched unintentional penalties for examples: criminal actions, spamming, credit cards frauds, phishing, identity theft, and other interrelated cybercrimes. This study wanted to consider cybercrime and its impact in an online banking in Nigeria. Adoption of ICT in banks really help them to enhance customer services, assisted precise records, guarantee suitable business hour, improve quicker services, also there has been advancement in the image of the banks which hints to a broader, quicker and more effectual market. Also it has enable work to be easier and more stimulating. The study set out to observe the impact of ICT tools for combating cybercrime in Nigeria online banking, the study approached the concern issue of cybercrime from the theoretical \& practical contribution perspectives. Data gotten from these research instruments were subjected to descriptive analysis \& regularity tallies in ways to describe the actions of Nigeria cybercriminals based on online banking and to know the way to use ICT tools in prevent these crimes.
\end{abstract}

Index Terms-ICT, cyber crime, online banking crime.

\section{INTRODUCTION}

Arrival of the internet technology grant both opportunity as well as contest to online banking, one of the main disadvantages in an online banking is the issue of security. Those customers that involve in online banking are assumed to be at the high hazard and danger of their information which is being shared with the other part of the world and confidentiality on their transaction. Particularly the Federal Republic of Nigeria which is well recognizes as one of the utmost cases of cybercrime and in that of internet security breaches. Online banking security has really turned to a gigantic worry to both the bank and the customers as a whole in Nigeria, we are currently said to be amidst 'another modern upheaval', one that will lead us into another sort of society, a data age [1]

Ref. [2] posits that the word Security merely refers to as managing risks, security is number one significant aspect in online banking sector. While the word online banking security humbly refers to managing of risks around banks that are reachable via a subjective computer, or laptop. In

Manuscript received June 30, 2015; revised September 18, 2015.

Fadare Olusolade Aribake is with Universiti Utara Malaysia, Malaysia (e-mail: fadareolusolade@yahoo.com). view of this, security and confidentiality are one of the biggest problem banks are combating with, in order to endure this competitive market. Alsmadi and Alwabel expressed that the definition of online banking varies among researchers partially because online banking refers to several types of services through which bank customers can request information and carry out banking services [3]. ICT tools such as user identification, transaction access code (TAC), password electronic token and SMS (short message services) alert, internet bank transfer, and bill payment, all these are the mainstream pre-emptive procedures used by the online banking in the Nigeria society to combats cybercrime in the banking sector. Nevertheless, these ICT tools are making online banking development to be extra difficult and intricate which is enrolling meek and lucidity nature of an ideal system. Execution of these ICT tools in combating cybercrime in Nigeria online banking sector has not in any way directly lessen the rate of online banking crimes.

The discoveries from [4] exposed that Nigeria online banking sector requires vast attention due to several cases of cybercrime comprising economic fraudsters, internet frauds and scams. Equally the country is undergoing insufficient functioning facilities like telecommunication and electric supply, these features were acknowledge as limitation disturbing the improvement of online banking in Nigeria.

In addition, the former chairman of Nigeria Economic Financial Crime Commission (EFCC) Waziri (2009) pointed out that the awful level about corruption and cybercrime as an impediment that might closed the entryway of improvement in contradiction of the country. In Nigeria, there has been an upward surge in the utilization of the cybercrime; a normal Nigerian utilizes a cellular telephone, while the internet infiltration is consistently developing. From 2000 to 2012, the nation has encountered increment in mobile users (demonstrated in Fig. 1) from a simple 30,000 (0.02 endorser every 100 inhabitants) to 112,777785 (67.68 supporters every 100 inhabitant), and an increment in internet subscription from 0.06 to 32.88 supporter every 100 inhabitant

Tragically this has prompted more ill-use of the same cybercrime, at the moment, Nigeria positions amid the nastiest awful nations regarding ill-use of ICT (Internet Crime Complaint Centre, "2010).

\section{OBJECTIVES OF THE RESEARCH}

The objectives of this study are as follows; to examine the impact of online banking ICT tool in militating against online banking crime in Nigeria commercial banks, to investigate the perception of online banking customers' 
toward online banking ICT tools in Nigeria commercial banks and to examine the attitude of online banking customers' toward online banking ICT tools in Nigeria commercial banks.

\section{Methodology AND SCOPE OF THE RESEARCH}

This study will examine online banking ICT tool impact on crime prevention in Nigeria online banking sector. This study proposes regression analysis using SPSS analytical tool to find out the result.

\section{LITERATURE REVIEW}

Internet already turn to become a worldwide network according [5] which brings together millions of computer situated in various countries and also exposed broad chances in obtaining and interchange data which is now been used by so many for illegal acts owed to the financial issues, Nigeria been a third world nation is confronted with diverse of financial challenges for instances corruption, unemployment, poverty, and so on, making crime a thrive.

The chapter broadly discusses the previous studies on ICT tools and the concept of cybercrime by highlighting its connection with this study based on the earlier stated research questions and the formulated objectives of the study. This chapter gives the theoretical part of the impact of cybercrime in an online banking system which has been an issue of interest for many decades in which different scholars have been able to carry out different research studies in diverse area of it to date. Below are the overview of the previous work carried out and the findings of some of these researchers and scholars.

Ref. [6] characterized cybercrime as a crime identified with technology, PC and the web in which it involve governments, commercial enterprises including the citizens global and cybercrime takes the system of both piracy, procurement of free phone calls, cyber bully, cyber terrorism \& cyber pornography.

In the years 2007 internet crime report itemised Nigeria name as third in terms of online crime action and the occurrence of cybercrime amid the sufficiently number of young Nigeria [7]

Ref. [8] on the other hand, simply defines cybercrime as any activity that uses the internet to commit a crime, in almost all the developed countries, there is a central database that has details of all citizens and has links to other databases such as the car registration database held at the drivers vehicle licensing agency and to another powerful computer running the automated fingerprint identification system. Also same thing has been applicable to foreigners in the developed countries in which all foreigner fingerprints, and international passport numbers is inside the database, this integrated system helps in tracking down and controlling crime.

Development of online banking additionally presents enriched opportunities for perpetrator of cybercrime; funds can be misappropriated making use of wire transfer account. Criminals might succumb fraudulent online request for bank loans, interrupt e-commerce by appealing in denial of services attacks also by conceding online banking imbursement systems, identity overthrow can influence online banking, just as new account can be taken over by identity thieves, thus levitation regarding the wellbeing soundness of economic organization. Therefore except crime uncovering and deterrence are antagonized communally, Nigeria like any other country will have to continue genuine breeding grounds for cartels of such criminal actions [9] A number of crime control and prevention initiatives have been implemented with the use of modern technology.

\section{ONLINE BANKING CRIME}

Ref. [10] refer Online banking might be the initiator of this new era environment and also the prime motivator in terms of making available the prospective clarification for banks subsistence in the years to come.

Ref. [11], Research already shown that online banking services are the upsurge of the forthcoming banking by making available massive aids to clients in terms of comfort and cost of dealings via online banking [12] and [13] states that online banking crime is a crime committed with the use of online technology to illegitimately eliminate money from a bank account or means of transferring money to an account in unlike bank. Online banking crime can be categorized as another method of identity theft which is regularly made imaginable via methods such as Phishing.

Here are some ways out in averting online banking crime: Protecting antivirus \& firewall, restricting the amount of personal information one permit to be in public domain, making use of low limit distinct credit card for online buying to minimise the possible loss of things go wrong [14]. Specified that online banking has apparently added advantages to customer in terms of their convenience where customers conducts routine banking transfer from the easy and security of any place where they want to transact from. [14] In their research of causes of customer interaction with the internet assisted online banking in getting the reason such as perceived usefulness ease of use, security convenience, and also responsiveness to services requirements to be a robust measure of the variation in customer interactions. [15] posit that online banking technology create a revolt by expanding the banking hours outside office hours and also outside nationwide restriction. Online Banking fraud is divided into three groups in which each of them postures a distinct threat to customers and organizations they are: identity theft, friendly fraud and internal fraud.

\section{The EVOLUTION OF ONLINE BANKING}

Ref. [16] stated the antecedent for the current online banking product \& services aloofness banking product and services above automated media from the initial 1980's. The word online turn out to be popular in the commencement of the 1990's and also referred as the use of a terminal, keyboard and TV or a monitor in order to have access to the banking system making use of a telephone line. Online service began in New York in 1981 when major four cities banks suggested online banking services (banks (Citibank, 
Chase Manhattan, Chemical and Manufacturers Hanover) using the videotext system

Online banking basically implies it do not comprise any physical interchange of money relatively it have to be done online or done electronically, from one account to another account with the aid of the internet. Online banking is like normal with a great exemption in which one do not have to go to the bank for any transaction rather one can access his or her account anywhere and at any particular time where ever in the whole wide world, this can be executed when one have the whole time to his or herself not only when the bank is being open. Deutsche Bank Report, 2006 the portion of online bankers do not lessening with age, propensity that people who shop online are also more eager to bank online alongside with Nordic countries for them to be more reactive to internet banking than their share of online purchasers would propose while Germans and British display a earmarked and persistent approach in the direction of online banking

\section{ADVANTAGES OF ONLINE BANKING}

There are several advantages of online banking, in which some of it implies that it is much convenient, it not bound with effective timing, also there are no topographical obstacles and the service can be offered at a microscopic price (IAMAI's, 2006).

Countless banks already initiated to suggest to customer possibility of online banking, a rehearsal which has a great advantage for all the parties which are involve. The accessibility of a great privilege to be able to have access to accounts at any period of time also the capacity to perform transactions without any need of going to a local branch, which cut the attraction of so many people to be part of it. ). Online banking has experience traditional practices in banking [17].

Some of these advantages of online banking include: customers accessibility, more efficient rate, service, mobility, and transfer, easy to use, environmental friendly.

\section{DISADVANTAGES OF ONLINE BANKING}

Online banking appears like an evident choice to leave the hassles of traditional money administration behindhand in altercation for it, also we have some prospective challenges accompanying alongside with banking over the internet whereas customer might not be mindful off. Customers really have to consider the advantages also the disadvantages of online banking before partaking in it [17]. Here are the selected disadvantages of online banking which include: bank relationship, transaction issues, services issues, security.

\section{Challenges of ONLINE Banking}

Initiating security for online banking is a mission which is normally easier said than done, safeguarding an online banking frequency has so many various facets to it each of them have to be looked into separately. privacy, honesty, and also verification are vital structures in the banking sector and they have been positively succeeded the world over in pre-internet period, communication crossway on an open and thus unconfident station such as the internet might not be the superlative base for customer relations as reliance might partly be misplaced.

A basic problem confronted by banks whenever they are upgrading their security substructure is being classifying which technology to be espoused and which portion of the substructure to modify or elevate. Aside from offering a vigorous and secure channel for online banking, banks basically have to agree on a clarification which only outfits with their desires, but also have to balance security, cost \& suitability for their customers.

\section{AtTitude OF CUSTOMER towards OnLine BANKING}

The invention of technology are having momentous meaning in human life over-all, this new age can carefully be credited as technology uprising. The rapid upraise of information communication technology has absorbed into different lives of millions of people, speedy technology improvement have introduced key vicissitude in the universal financial and business stratosphere [18].

The study on consumer attitude towards the direction of online banking already displayed that there are numerous features deciding the customer's attitude towards the online banking and these are: person's demography, motivation \& behaviour towards different banking technology and individual acceptance of the new technology. It was also discovered that customers attitude in the direction of online banking are persuaded by the preceding knowledge of computer and the new technology [19].

Based on [20], customers do have limited period to devote of actions such as stopping by at the bank and therefore need an utmost degree of suitability \& availability. The service excellent features which the internet banks have to provide in order to persuade consumers to shift to online banking transaction and preserve in using them are perceived usefulness, ease of use, dependability, approachability, security, and unceasing upgrading [14].

From that of [21] study, open up on six compound extents of online banking services superiority, comprising the provision of suitable/precise online banking operation, the approachability and dependability of service provision, virtuous line management, services personalization, establishment of pleasant and receptive customer service, provision of besieged customer services. Perceived usefulness security confidentiality are the key examining features to receive online banking system [18].

\section{Perception OF Customer TOWARds OnLINE BANKING}

We have a developing curiosity in sympathetic, the users involvement [22], as it is perceived as a superior perception than user gratification, from this perceptive measuring the customer knowledge is vital for countless technology product and services [23]. The new technology brought extensive uprising in humanities, in which it has extremely changed most business banking prospects.

Customers already started in perceiving the service of online banking through the use of the internet as a major good-looking feature than any other key product features of 
the bank, customer already begin in assessing the banks based on the suitability and luxury it offers to them [23]. Bankers now start in emerging numerous product structures and services making use of internet application. [24] discover that most of the active customer's user of online banking makes use of it just because of its convenient, and also being time saving and suitable for all their transactions desires. More so the network security and the security of the system when it comes to privacy are the main disquiets of the users and constitute restriction to proposing users.

\section{INFORMATION COMMUNICATION TECHNOLOGY (ICT)}

A prevalent research interest in awareness of Information Communication Technology (ICTs), agreeing to [25] regard ICTs are significantly vital for maintainable development in rising the country as a whole. [26] notes that for the few years back eras almost advance countries already countersigned substantial vicissitudes which can be drawn to ICTs, show that so many creativities have taken over at the international level in backing up all Africa's countries, plus Nigerian finding quicker methods to accomplish durable and endurable growth. [27] discusses ICT as a civilization in which the value of life as well as the prospects for social vicissitudes \& financial growth rely progressively on information and its utilization.

\section{TRANSACTION AUTHORISATION CODE (TAC)}

A transaction authorization code (TAC) is the consent code make available by the card issuer to the supplier at the time of the transaction [28]. It is convenient to use TAC in my online banking transactions, the cardholders getting to the transaction access code into the keypad of the card sources are authentically making use of card to exhibit a figure identical to the transaction consent code make available by the issuer. The authorization code and the equivalent consent code can be used to validate a card transaction to additional relief in fraud deterrence. TAC enables you to feel secure using it in your online banking transaction [29].

TAC is always in a distinctive security code of 6-digit number use for registration \&reset connect, online account settings and maintenance, specific online banking transaction.

\section{PASSWORD ELECTRONIC TOKEN}

Token can be referred to as a device in which an authorized user of computer services is given to for comfort authentication. Token is been use to prove one's self with the aid of electronic means, Using token prevent me from cyber fraud [29]. Token is been use in tallying to or in place of a password to verify that the customers is who they assertion to be. Token can be in two types: Hardware token \& Software token. We have two elective inputs to token: Token input data \& Token activation data.

\section{SignifiCANCE OF ICT IN AN ONLINE BANKING}

[30] ICT uprising has mislead the conformist banking business ideal by making it imaginable for banks to breakdown their relaxation arena and value formation chain in order to permit customer service delivery to be detached into diverse businesses. For instant, predominantly internet banks dispense insurance and securities also applicable to all the banking products, but not all the product dispersed are fashioned by their cluster. Though, core monetary dispute for dispersion of embracing internet as a conveyance station is centered on the estimated discount in above expenditure made imaginable by decreasing and ultimately eradicating physical outlets with their accompanying costs.

Ref. [31] states that the online conveyance outlet may produce gage economics in surplus to those accessible to traditional dissemination stations. Outwardly, there are permanently possibilities of disaster which make bank to tolerate insufficiency, ICT innovative buttressed by a greater machinery regulator is mandatory to make assured that ICT has attained the compulsory procedures inadequacy, advance information system maintained by higher instrument regulator is compulsory to make certain that ICT attained the necessary procedures.

\section{EFFECTS OF ICT IN AN ONLINE BANKING}

As stated by [32], Cybercriminals makes use of snifters or also by conjecturing passwords to breach security greatly lessening the usefulness of passwords when users do not handpick sagely crime always devalue a nation, and Nigeria has had its own fair share, more so we can never underrate the rate of harm Yahoo (Cyber Fraud) has basically cause the nation, also caused us globally and the ultramodern impact on the Nigeria system as a whole. The level of cybercrimes benefaction in Nigeria is one of the motives why crimes are seen as a custom within our entire environment.

The issue of cyber-crime is a worldwide one whose magnitude, extent and effect echo all over different treads of life, leaving previously inconceivable injury in its wake. This is generally mentioned as yahoo yahoo ailment, in Nigeria these deceitful acts and happenings are being carried on by the disobedient ones, the impact is far getting due to the global spread of the internet. Cybercrime is not just one discomfiture rather it also have destructive insinuation for encouraging deployment of ICT for socio economic development \& enlargement. With an opinion in dealing with some of the issues elicited with cybercrime, Nigeria government organized some legal and plus the mobilization of the Economic and Financial Crime Commission EFCC (2009).

Ref. [33] deliberated on the effect of the computer automation on the banking services welfares to Lagos and discovered that online banking has tremendously improved some benefits concerning some of the banks to their customer in Lagos. This study was restricted to lucratively bravery emphasis from Nigeria and engaged looking into just six few numbers of banks, he made some comparative enquiry among the old and new generation banks and publicized later in variation in the rate for espousal of the robotized devices.

Discovery made by [23], revealed that banking in Nigeria has progressively rest-on the placement of information technology \& that of IT budget for banking is far-far bigger 
than that of any other organization in Nigeria.

\section{CYBERCRIME IN AN ONLINE BANKING}

It was already perceived that till the middle of 1990 banking segment in almost all area of the world was so simple and much dependable, ever since the initiation of technology the banking sector witness an exemplar swing in the marvel [34].

In the directive for banks to improve their customer base presented so many stages via which transactions can be done without copious struggle [35].

The new advent of technology empowered the customer to have access to their bank finances $24 \times 7$ throughout the year, ATMs and the online banking techniques. However with the help of the improvement in technology banking frauds already grown more than before [36].

There have being diverse means for cybercriminal to get in touch with one's bank information and in due course getting in touch with their money as well [37].

Ref. [38] specified that crime and misuse talk to a important compassion in the direction of business managers in Nigeria as well as in various area of Africa. In Nigeria, for event, the utmost constraints to economic actions and business are crime and misuse which center is nearby $75 \%$ and $70 \%$ independently.

\section{RELATIONSHIP BETWEEN ICT TOOLS AND ONLINE BANKING FOR CRIME}

The uprising of information communication technology (ICT) has had impacts in every aspect of human endeavour, ICT has also bought accidental penalties such as criminal deeds, spamming, credit card frauds, ATM frauds, phishing, identity theft and other interrelated cybercrime. This study wanted to evaluate cybercrime and its influence on the banking industry in Nigeria [39] In as much as banking industry is going the way in turning global in nature, banks are required to equilibrium the aim of outreach and endure ability to allow banks to overwhelmed limits, approve tactical outlook and bring in new potentials. [40] ICT has abridged the cost of processing and enabling the transmission of data turning to radical vicissitudes in the banking sector.

Ref. [41] further discuss that funds are been transferred automatically with the help of the ATMs to offer retail banking services permitting it 2-4-7 a day to day transaction, balance confirmation and bill disbursement at outlets including isolated places.

It is worth nothing that online banking has never been at any particular time restricted to advance nations, but also seen even in countries that are still underdeveloped as an outcome of so many various new business chances obtainable by online banking.

Ref. [42] ICT uprising both terms of improvement rate, quick operation, and worth-per-unit representing decrease in middling overall marginal prices, already made a virtuous number of banks to cuddle the use of ICT substructure in there procedures in mandate to be prevented from online banking crime, ICT already enable online banking to turn out to be best channels to offer banking service products available to customers, the excellence of online banking services has turned out to be a chief aspect of consideration amid researchers and the bank managers due to its solid impact on business presentation, lucrativeness and customer service delivery.

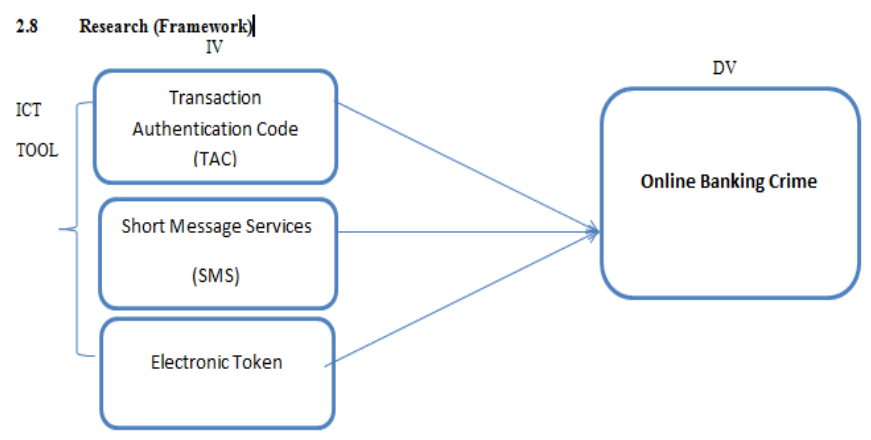

Fig. 1. Research hypotheses.

H1 ICT tool TAC negatively influence online banking crime

H2 ICT tool SMS negatively influence online banking crime

H3 ICT tool Token negatively influences online banking crime.

\section{CONCLUSION}

Internet and Communication Technology has influenced every wake of our life in one or other way. Cybercrime with its complications has confirmed difficult to combat due to its nature. The battle alongside malefaction involves a unified and synchronized tactic encouraged by dynamic ICT security system. Thus, there is a need for a cyber-activities guideline that safe-guards Nigerians within and outsiders interested in capitalizing in Nigeria. Also, the fight against cybercrime and cyber security threats in Nigeria entails not just understanding of Information Technology but Information Technology intellect on the part of all residents.

\section{REFERENCES}

[1] G. Z. Williams, Business Research Methods, Thomson South Western Inc. USA, 7th ed., 2003.

[2] D. C. Mayriam, "Cyber-security, and threat politics," US Efforts to Secure the Information Age, London: Routledge, 2008.

[3] M. O. Al-Smadi and S. A. Al-wabel, "The impact of electronic banking on the performance of jordanian bank," Journal of Internet Banking and Commerce, vol. 16, no. 2, 2011.

[4] O. A Ojeka, Electronic Commerce, Automatic and Online Banking in Nigeria: Challenges and Benefit, 2012.

[5] G. Vladimir. (2005). International cooperation in fighting cyber crime. [Online]. Available: http://www. crimeresearch.org

[6] B. H. Schell and M. Clemens, Cybercrime: 2004, A Reference Handbook $A B C$ - CLIO

[7] G. Sesan. (2010). The New Security War. [Online]. Available: http://www.pcworld.com/article/122492/the_new_security_war.htm\# tk.mod-rel

[8] H. Milhorn, Cybercrime: How to Avoid Becoming a Victim by True Crime, 2007

[9] E. Ribadu, "Cyber crime and commercial fraud; A Nigerian perspective," presented at the Modern Law for Global Commerce, Vienna, 2007.

[10] F. L. Anyasi and P. A. Otubu, Mobile Phone Technology in Banking System: Its Economic Effect, 2009.

[11] T. Hazlina, "Impacts of service quality on customer satisfaction: Study of online banking and atm services in Malaysia," International Journal of Trade, Economics and Finance, vol. 2, no. 1, pp. 10-23, 2011 . 
[12] S. M. Nsouli and A. Schaechter, "Challenges of the e-banking revolution: Finance and development," International Monetary Fund, vol. 39, no. 3, pp. 231-254, 2002.

[13] T. Markku, "Impact of future trends on banking services," Journal of Internet Banking and Commerce, vol. 17, no. 2, pp. 271-295, 2012.

[14] Z. Liao and M. T. Cheung, "Measuring customer satisfaction in internet banking; A core framework," Communications of the ACM vol. 51, no. 4, pp. 47-51, 2008.

[15] K. G. Balachandran, "Online-banking development in Malaysia: Prospects and problems," 10 JIBL, p. 250, 2000.

[16] M. J. Cronin, Banking and Finance on the Internet, Toronto: John Wiley and Sons, 1997.

[17] M. E. Gonzalez, "An alternative approach in service quality: An ebanking case study 2008," Quality Manage, vol. 15, pp. 41-48.

[18] T. M. Qureshi, M. K. Zafar, and M. B. Khan, "Customer acceptance of online banking in developing economies," Journal of Internet Banking and Commerce, vol. 13, no. 1, 2008.

[19] S. Laforet and X. Li, "Consumers' attitudes towards online and mobile banking in China," International Journal of Bank Marketing, vol. 23, no. 5; pp. 362-380, 2005.

[20] J. Delvin, "Technology and innovation in retail banking distribution," International Journal of Bank Marketing, vol. 13, pp. 19-25, 1995.

[21] E. E. Ibrahim, M. Joseph, and K. I. N. Ibeh, "Customers' perception of electronic service delivery in the UK retail banking sector." International Journal of Bank Marketing, vol. 24, no. 7, pp. 475-493, 2006.

[22] M. Hiltunen, M. Laukka, and J. Luomala, "Mobile user experience," Logistics Information Management, vol. 161, pp. 64-73, 2002.

[23] J. Ovia, "Enhancing the efficiency of the payment system in Nigeria", CBN Bullion, vol. 29, no. 1, pp. 8-18, 2005.

[24] A. Charles, "An empirical investigation of the level of users acceptance of e-banking in Nigeria." Journal of Internet Banking and Commerce, vol. 15, no. 1, 2010.

[25] A. Credé and R. E. Mansell, Knowledge Societies in a Nutshell: Information Technology for Sustainable Development, 1998.

[26] R. M. C. Thioune. (2003). Information and communication technologies for development in Africa: Opportunities and challenges for community development. [Online]. Available: http://www.idrc.ca

[27] J. W. Martin, The Global Information Society, England: Aslib, 1995, p. 3

[28] T. C. E. Cheng, D. Y. C Lam, and A. C. L. Yeung. "Adoption of internet banking: an empirical study in Hong Kong," Decision Support System 2006, vol. 42, no. 3, pp. 1558-1572, 2004.

[29] C. S. Yiu, K. Grant, and D. Edgar, "Factors affecting the adoption of internet banking in Hong 1020 Kong - implications for the banking sector," Int J Inform Manage, vol. 27, pp. 336-351, 2007.

[30] J. Delgado, I. Hernando, and M. J. Nieto, "Do European primarily internet banks show scale and experience efficiencies," European Financial Management, 2006.
[31] R. De Young, "The performance internet- based business models: Evidence from the banking industry," Journal of Business, vol. 78, no. 3, pp. 893-947, 2005.

[32] E. E. Adomi, "Security and software for cybercafes," IGI, USA, 2008

[33] A. A. Agboola, 2001, "Impact of electronic banking on customer services in Lagos Nigeria in Ife," Journal of Economics and Finance, Department of Economics, O.A.U, Ile-Ife, Nigeria.

[34] R. Jaleshgari, "Document trading online," Information Week, vol. 755 , no. $136,1999$.

[35] M. Vrancianu and L. A. Popa, "Considerations regarding the security and protection of e-banking services consumers interests," The Amfiteatru Economic Journal, vol. 1228, pp. 388-403, 2010.

[36] H. Alaganandam, P. Mittal, A. Singh, and C. Fleizach, Cybercriminal Activity, 2007.

[37] K. K. Choo, "The cyber threat landscape Challenges and future research direction," Computers \& Security, vol. 308, 719-731, 2011.

[38] O. O. Olasanmi, "Computer crimes and counter measures in the Nigerian banking sector," Journal of Internet Banking \& Commerce, vol. 15 , no. 1, pp. 1-10, 2010.

[39] A. A. Aliyu and R. Tasmin, "The impact of information an communication technology on banks' performance and customer service delivery in the banking industry," International Journal of Latest Trends Finance and Economy, vol. 2, no. 1, pp. 80-90, 2012.

[40] R. R. Nitsure, Online Banking: Challenges and Opportunities. Economic and Political Weekly, vol. 38, no. 51/52, pp. 5377-5381, 2003.

[41] A. R. Gourlay and E. J. Pentecos, "Impact of network effects on technology adoption: evidence from the adoption of automated teller machine," Journal of Manchester School, vol. 70, no. 2, pp. 185-203, 2002.

[42] O. M. Akinuli, "Information technology in Nigeria's banking industry: Operational applications, problems and future challenges," CBN Bullion, vol. 23, no. 3, pp. 71-75, 1999.

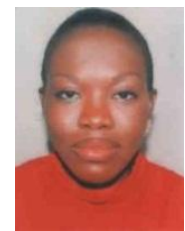

Fadare Olusolade Aribake was born on November 2, 1986 in Owo, Ondo State. She attended and graduated from Nigeria Universiti Utara Malaysia, MSC (ICT) in 2015. She worked at FIRST BANK PLC 47, Area ' $H$ ' Police Station Ogudu, Lagos Nigeria as a marketing executive between 2008 and 2012. At the bank, she was charged with the following responsibilities: mobilizing deposits and selling retail loans to both new and existing customers, marketing of all the bank's retail products and account opening documentations. Because of her love for academics, she resigned in 2012 to pursue her M.Sc. in ICT at the Universiti Utara Malaysia. Her research interests are ICT, statistics and business management. 